\title{
PALAE0
}

Palaeogeography, Palaeoclimatology, Palaeoecology 129 (1997) 155-169

\section{5,000-year late Quaternary records of carbonate preservation in the South China Sea}

\author{
Min-Te Chen ${ }^{\mathrm{a}, 1}$, Chi-Yue Huang ${ }^{\mathrm{b}}$, Kuo-Yen Wei ${ }^{\mathrm{b}}$ \\ ${ }^{a}$ Institute of Applied Geophysics, National Taiwan Ocean University, Keelung 20224, Taiwan \\ ${ }^{\mathrm{b}}$ Department of Geology, National Taiwan University, Taipei 10770, Taiwan
}

Received 22 August 1995; revision 18 June 1996; accepted 18 June 1996

\begin{abstract}
Pelagic sediments recovered from the South China Sea (SCS) exhibit characteristic carbonate preservation fluctuations that are closely linked to major cycles of climatic change. Two deep sea cores (SCS 90-36: 17 $59.70 \mathrm{~N}$, $111^{\circ} 29.64^{\prime} \mathrm{E}$, water depth $2050 \mathrm{~m}$; and $31-\mathrm{KL}: 18^{\circ} 45.4 \mathrm{~N}, 115^{\circ} 52.4^{\prime} \mathrm{E}, 3360 \mathrm{~m}$ ) that are located respectively above and below the regional lysocline $(\sim 3000 \mathrm{~m})$ were selected for studying the late Quaternary pattern of carbonate preservation in the SCS. Preservation indices measuring changes in the abundances of dissolution-resistant planktonic foraminifers and coccoliths, and in ratios of foraminiferal fragments, benthonic foraminifers, and radiolarians, have revealed increased carbonate preservation during the last glacial period and/or during the last deglaciation (Termination I; $\sim 12,000$ k.y.), but stronger carbonate dissolution during the interglacial period of the Holocene. Detailed comparisons of preservation and oxygen isotope records further indicate that the level of carbonate preservation increased steadily from 25 k.y. through Termination I and that preservation reached a maximum during Termination I. From Termination I into the Holocene, however, the level of preservation decreased gradually to a minimum. Both records exhibit noticeable glacial/interglacial variations ( $1 / f$ on the order of $10^{4}$ years), while the higher resolution record of $31-\mathrm{KL}$ records a series of higher frequency oscillations ( $1 / f$ on the order of $10^{3}$ years). These data confirm the observation that maximal carbonate preservation tends to occur during the later half of glacial stages as shown previously in many Indian and Pacific deep sea core studies.(C) 1997 Elsevier Science B.V. Allrights reserved.
\end{abstract}

Keywords: paleoceanography; paleoclimatology; Quaternary; Pacific Ocean

\section{Introduction}

Studies on air trapped in Vostok polar ice cores (Barnola et al., 1987) have shown that atmospheric carbon dioxide concentrations $\left(p \mathrm{CO}_{2}\right)$ during the last ice age were significantly lower than during the preindustrial Holocene - about 200 ppm com-

\footnotetext{
'Tel: 886 (2) $462-2192 \times 6503$, FAX: 886 (2) 462-5038, e-mail: chenmtb212@ntou66.ntou.edu.tw.
}

pared to $280 \mathrm{ppm}$. Attempts to explain atmospheric $p \mathrm{CO}_{2}$ changes on this time scale focus on ocean chemistry and circulation (Shackleton, 1977; Broecker, 1982a,b) since the ocean acts as a large reactive carbon reservoir that must play an important role in the global carbon cycle.

The preservation of calcium carbonate sediments on the sea floor provides important information about the carbon-carbonate chemistry of the oceans. Over the time scale of orbital variations 
$\left(10^{4}-10^{5}\right.$ years), the change in the saturation state of carbonate in $\mathrm{CO}_{2}$-rich deep waters depends primarily on the global mass balance of carbonate and the vigor of deep ocean thermohaline circulation. Previous investigations on deep sea carbonate records from the Pacific (Arrhenius, 1952, 1988; Chuey et al., 1987; Farrell and Prell, 1989, 1991; Archer, 1991; Le and Shackleton, 1992) and the Atlantic (Ruddiman, 1971; Gardner, 1975; Damuth, 1975; Curry and Lohmann, 1986) indicate that the Pacific preservation pattern is out of phase with that of the Atlantic. Good preservation conditions occurred during glacial periods in the Pacific but during interglacial periods in the Atlantic. This asymmetry between the Pacific and Atlantic preservation patterns has been attributed to changes in basin-to-basin fractionation resulting from variations in North Atlantic Deep Water (NADW) production (Berger and Winterer, 1974). Carbonate preservation records of the Indian Ocean (Peterson and Prell, 1985a,b; Naidu et al., 1993: Bassinot et al., 1994) exhibit a Pacifictype pattern with good preservation during glacial periods and poor preservation during interglacial periods. Detailed comparisons of Indian carbonate preservation and oxygen isotope records further indicate that preservation maxima and minima tend to occur during the latter half of glacial and interglacial periods, respectively (Peterson and Prell, 1985b). These phase relationships were later confirmed in central equatorial Pacific studies (Farrell and Prell, 1989, 1991) in which the bathymetric variations in carbonate preservation of the past 800,000 years were reconstructed by using transects of deep sea cores.

The deep sea cores used in the previous studies (Peterson and Prell, 1985b; Farrell and Prell, 1989, 1991 ) were drilled from open oceans. Sedimentation rates of these cores approximated $2-3 \mathrm{~cm} / \mathrm{k} . \mathrm{y}$, which were too low to be used to identify rapid climatic changes of the phase lagging patterns which vary on the time scale of only one thousand year. In this study, we used high-resolution deep sea records SCS $90-36\left(17^{\circ} 59.7^{\prime} \mathrm{N}, 111^{\circ} 29.6^{\prime} \mathrm{E}\right.$; $2050 \mathrm{~m})$ and $31-\mathrm{KL}\left(18^{\circ} 45.4^{\prime} \mathrm{N}, 115^{\circ} 52.4^{\prime} \mathrm{E}\right.$; $3360 \mathrm{~m}$ ) from the South China Sea (SCS) to investigate the temporal changes in carbonate preservation during the last glacial/interglacial climatic change of the past $25,000 \mathrm{yr}$ (Fig. 1). Average sedimentation rates are estimated at $4.0 \mathrm{~cm} / \mathrm{k} . \mathrm{y}$. for SCS $90-36$ and $6.7 \mathrm{~cm} / \mathrm{k} . \mathrm{y}$. for $31-\mathrm{KL}$. These high sedimentation rates permit the recovery of short-term climatic signals, especially during the last glacial-to-interglacial transition. Previous studies (Wang, 1992; Bian et al,, 1992; Cheng, 1992; Wang and Jian, 1992; Thunell et al., 1992) have documented changes in carbonate accumulation and preservation patterns in the SCS during the last glacial/interglacial period. Little information is available, however, on the relationship between carbonate preservation and climatic changes during this time. In this paper, we present a reconstruction of carbonate preservation patterns in the SCS during the past 25,000 yrs based on multiple sedimentological and micropaleontological indices of carbonate preservation from these two high-resolution records. With reliable age controls provided by AMS ${ }^{14} \mathrm{C}$ dating and oxygen isotope stratigraphic correlation methods, we show that the carbonate preservation level was enhanced during the last glacial and reached a maximum between 13,000 and 11,000 k.y. Carbonate preservation levels decreased suddenly starting about $11 \mathrm{k} . \mathrm{y}$. and have continued to decrease up to the present. This pattern is consistent with that predicted by geochemical models (Berger and Winterer, 1974; Broecker and Peng, 1987; Boyle, 1988).

\section{Data and methods}

\subsection{Stratigraphy and age model}

The age models for cores SCS $90-36$ and $31-\mathrm{KL}$ were established by the use of AMS ${ }^{14} \mathrm{C}$ dating (Table 1) and oxygen isotope stratigraphic correlation (Imbrie et al., 1984; Prell et al., 1986). The ${ }^{14} \mathrm{C}$ dating control points that were used to obtain the chronology of the cores give consistently older ages with depth (Table 1). These ${ }^{14} \mathrm{C}$ ages correlate well with the age scheme estimated from oxygen isotope curves of planktonic foraminifers (Figs. 2 and 3 ). The ages of sediment samples between the control points of these age models were obtained by linear interpolation, and such comparisons 


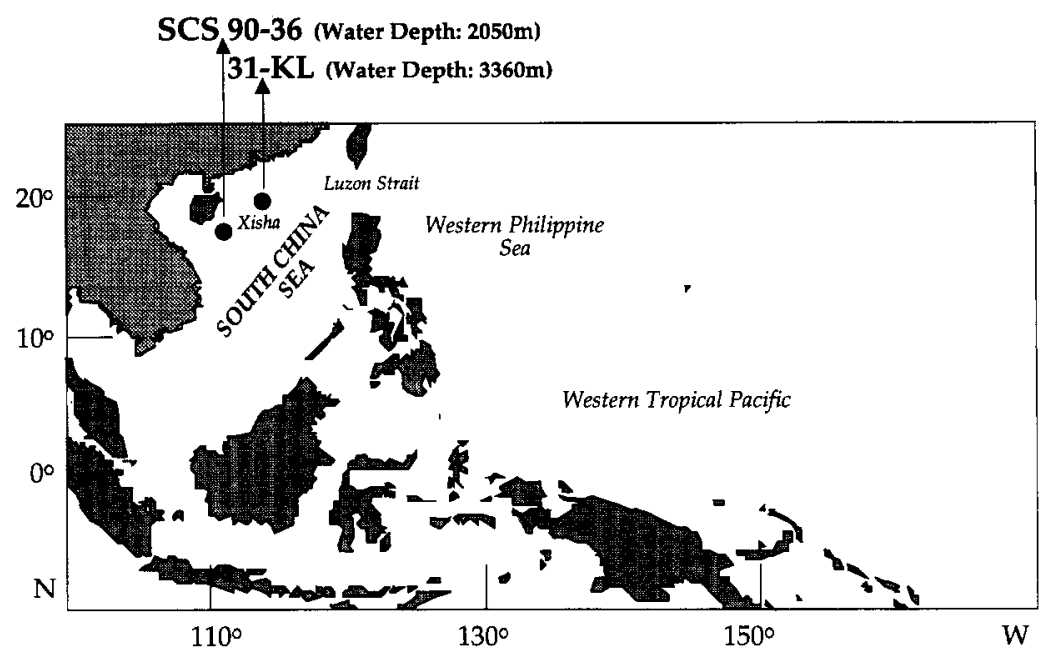

Fig. 1. Location map showing positions of South China Sea (SCS) core sites SCS 90-36 and 31-KL used in this study.

allowed estimates of carbonate sedimentation rates to be made (Table 1). The unexpectedly low sedimentation rates prior to $16 \mathrm{k} . \mathrm{y}$. in core SCS $90-36$ seem unreliable and may have resulted from erosion or a depositional hiatus such as has been observed near the Xisha Trough (Kudrass et al., 1992).

\subsection{Preservation indices}

Variations in carbonate preservation reflect primarily the calcium carbonate saturation state of bottom waters and interstitial pore waters. It can be assumed that the state of fragmentation of foraminifers is controlled by the preservation conditions under which the sediments were deposited, so that the percentages of foraminifer fragments increase as the sedimentary environments become more corrosive (Berger, 1967). Studies based on sediment-trap data have shown a linear increase in foraminiferal fragmentation with decreasing carbonate weight (Berger, 1967; Thunell and Honjo, 1981; Thunell et al., 1981). Similarly, data from surface sediment studies reveal increasing fragmentation with decreasing carbonate accumulation rate (Curry and Lohmann, 1986) and increasing carbonate loss (Peterson and Prell, 1985a). The fragmentation index is now the most widely used indicator of carbonate preservation in deep-sea core studies (Thunell, 1976, 1982; Peterson and Prell, 1985a; Prell, 1984b; Le and Shackleton, 1992; Howard and Prell, 1994). Similar bathymetric trends are also observed for percentage variations in benthonic foraminifers or radiolarians (Peterson and Prell, 1985a), indicating a similar sensitivity to preservation changes for these indices.

The depth level where an abrupt change in dissolution rate gradients separate well preserved from poorly preserved sediments is termed the lysocline, and its depth is determined by a balance of three processes: (1) $\mathrm{CaCO}_{3}$ productivity of calcareous planktonic organisms (foraminifers, pteropods, and coccoliths), which increases the supply of biogenic $\mathrm{CaCO}_{3}$ sediments to the sea floor and in turn leads to better preservation; (2) non- $\mathrm{CaCO}_{3}$ productivity of siliceous planktonic organisms (radiolarians and diatoms), which increases the downward flux of organic carbon and $\mathrm{CO}_{2}$ and results in increased dissolution in bottom water. In the SCS, some of organic matter inputs into the ocean may be attributed to the supply of terrigenous materials from the Asian Continent; and (3) production and circulation patterns of intermediate and deep waters, the distribution of which, as well as their degree of corrosiveness, change with age. The modern position of the lysocline depth in the SCS has been 
Table 1

AMS ${ }^{14} \mathrm{C}$ dating and sedimentation rate of cores $\operatorname{SCS} 90-36$ and $31-\mathrm{KL}$

\begin{tabular}{|c|c|c|c|}
\hline $\begin{array}{l}\text { Depth } \\
(\mathrm{cm})\end{array}$ & $\begin{array}{l}{ }^{14} \mathrm{C} \text { age } \\
\text { (k.y.) }\end{array}$ & $\begin{array}{l}\text { Error bar } \\
( \pm \text { k.y. })\end{array}$ & $\begin{array}{l}\text { Sedimentation rate } \\
(\mathrm{cm} / \mathrm{k} . \mathrm{y})\end{array}$ \\
\hline \multicolumn{4}{|c|}{ SCS 90-36 } \\
\hline 0 & 1.3 & 0.1 & 45 \\
\hline 27 & 7.3 & 0.1 & 62 \\
\hline 51 & 11.2 & 0.1 & 5.7 \\
\hline 63 & 13.3 & 0.1 & 17.2 \\
\hline 87 & 14.7 & 0.1 & $0.8(?)$ \\
\hline 90 & 15.5 & 0.1 & $0.8(?)$ \\
\hline 96 & 22.9 & 0.2 & $1.6(?)$ \\
\hline 105 & 28.5 & 0.2 & \\
\hline 31-KL & & & \\
\hline 5 & 1.8 & 0.1 & 7.0 \\
\hline 35 & 6.1 & 0.1 & 4.5 \\
\hline 41 & 7.4 & 0.1 & 10.9 \\
\hline 81 & 11.1 & 0.1 & 14.1 \\
\hline 133 & 14.8 & 0.2 & 19.4 \\
\hline 273 & 22.0 & 0.2 & 10.7 \\
\hline 301 & 24.6 & 0.3 & \\
\hline
\end{tabular}

estimated to be $3000 \mathrm{~m}$ (Rottman, 1979), which is shallower than the $3400-3800 \mathrm{~m}$ reported in the western tropical Pacific (Parker and Berger, 1971; Thompson, 1976; Valencia, 1977; Berger et al., 1982).

We have used a variety of commonly used sedimentological and micropaleontological indicators to measure the relative changes of carbonate preservation in downcore samples from the SCS. The indicators used include: (1) percentage of dissolution-resistant planktonic foraminifer species (RSP\%); (2) percentage of whole planktonic foraminifers $(\mathrm{WPF} \%)=100 \times$ number of whole planktonic foraminifers/(number of whole planktonic foraminifers + number of planktonic foraminifer fragments); (3) percentage of dissolution-susceptible nannoplankton species; (4) ratio of dissolutionsusceptible nannoplankton $=$ number of dissolution-susceptible nannoplankton/(number of dissolution-susceptible nannoplankton + number of dissolution-resistant nannoplankton); (5) percentage of benthonic foraminifers $=100 \times$ number of whole planktonic foraminifers/(number of whole planktonic foraminifers + number of benthonic foraminifers); and ( 6 ) percentage of radiolarians = $100 \times$ number of whole planktonic foraminifers/ number of whole planktonic foraminifers + number of radiolarians). For core SCS 90-36 indices 1, 2, 3, and 4 were used (Fig. 2; Table 2), and for core $31-\mathrm{KL}$ indices $1,2,5$, and 6 were used (Fig. 3; Table 3). Since we were able to develop age models for these two cores based on AMS ${ }^{14} \mathrm{C}$ dating and oxygen isotope stratigraphies, we present these preservation index data relative to age rather than core depth. The time series of the preservation indices from these two cores are shown in Figs. 2 and 3, and are arranged in the same direction as preservation-dissolution changes.

The concept of using percentages or ratios of dissolution-susceptible and dissolution-resistant fossil species as preservation indicators was proposed earlier by Berger $(1967,1968)$. A systematic study of Indian Ocean surface sediment data (Cullen and Prell, 1984) indicated that a summation index of the percentages of fourteen dissolution resistant planktonic foraminifer species (RSP\%) could be used to reconstruct the depth of the lysocline. This same formula for calculating RSP\% was used in the present study. During the course of sample processing, we counted at least 300 specimens of whole planktonic foraminifers for the abundance analyses.

Changes in the abundance of dissolution-susceptible nannoplankton species and in the ratio of the susceptible vs. resistant nannoplankton species can also be used as sensitive indicators for carbonate preservation. For the nannoplankton analyses, we counted at least 700 specimens for each sample. The taxonomy scheme used here is primarily based on the criteria outlined by Rahman and Roth (1989), Matsuoka and Okada (1989), and Biekart (1989). Explanation for the taxonomic criteria is 


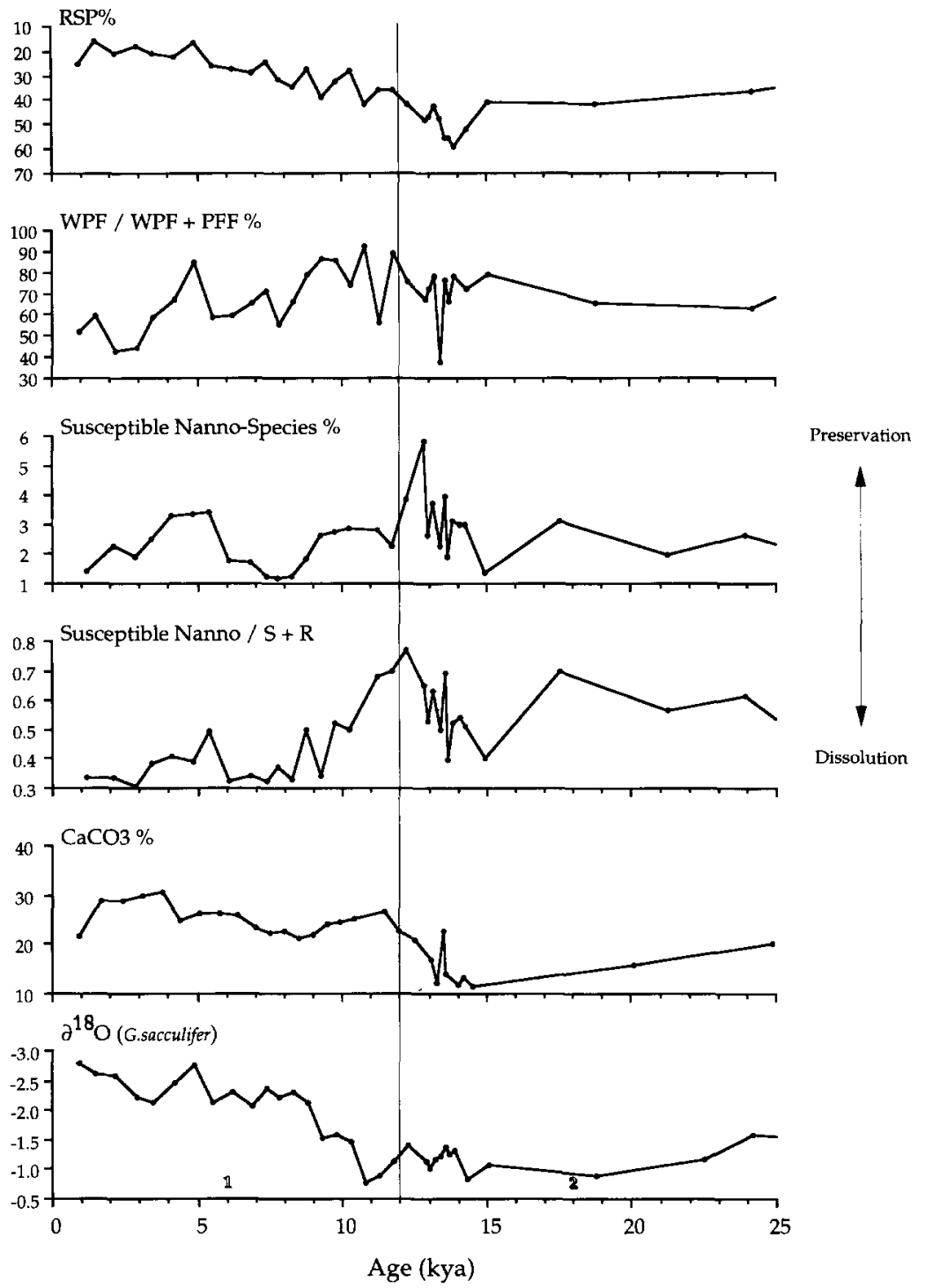

Fig. 2. Variations in carbonate preservation indices for core SCS $90-36$, compared to downcore AMS ${ }^{14} \mathrm{C}$ dating and $\partial^{18} \mathrm{O}$ stratigraphy (G. sacculifer) and plotted against age. A line shows the boundary between $\hat{\partial}^{18} \mathrm{O}$ stage 1 and stage 2 . Abbreviations for the preservation indices are explained in Table 2.

also given in Wei et al. (in press). The following nannoplankton species were defined as susceptible species: Umbellosphaera tenuis, U. irregularis, Thoracosphaera spp., Syracosphaera pulchra, Rhadosphaera longistylis, $R$. clavigera, Oolithotus fragilis cavum, $O$. fragilis fragilis, Discosphaera spp., Cyclolithus annula. Resistant species are: Umbilicosphaera sibogae sibogae, $U$. spp.,
Helicosphaera carteri, H. hyalina, H. kamptneri, H. wallichi, Ceratolithus cristatus, Calcidiscus leptoporus.

Carbonate contents $\left(\mathrm{CaCO}_{3} \%\right)$ in cores SCS 90-36 and 31-KL (Figs. 2 and 3) are relatively low, ranging from approximately 10 to $30 \%$. Our analyses show that the low carbonate contents primarily reflect dilution by terrigenous material, 
Table 2

Preservation indices of downcore samples from core SCS 90-36

\begin{tabular}{|c|c|c|c|c|c|c|c|c|c|}
\hline $\begin{array}{l}\text { Core } \\
\text { ID }\end{array}$ & $\begin{array}{l}\text { Depth } \\
(\mathrm{cm})\end{array}$ & $\begin{array}{l}\text { Age } \\
\text { (k.y.) }\end{array}$ & $\begin{array}{l}\operatorname{RSP}^{1} \\
(\%)\end{array}$ & $\begin{array}{l}\mathrm{WPF}^{2} /\left(\mathrm{WPF}+\mathrm{FG}^{3}\right) \\
(\%)\end{array}$ & $\begin{array}{l}\text { Core } \\
\text { ID }\end{array}$ & $\begin{array}{l}\text { Depth } \\
(\mathrm{cm})\end{array}$ & $\begin{array}{l}\text { Age } \\
\text { (k.y.) }\end{array}$ & $\begin{array}{l}\text { Nanno- } \mathrm{S}^{4} \\
(\%)\end{array}$ & $\begin{array}{l}\text { Nanno-S } /\left(\mathrm{S}+\mathrm{R}^{5}\right) \\
(\%)\end{array}$ \\
\hline SCS 90-36 & 0 & 0.9 & 25.1 & 51.5 & SCS $90-36$ & 2 & 1.2 & 1.4 & 0.3 \\
\hline SCS 90-36 & 3 & 1.5 & 16.0 & 59.5 & SCS $90-36$ & 6 & 2.1 & 2.3 & 0.3 \\
\hline SCS 90-36 & 6 & 2.2 & 21.2 & 42.3 & SCS $90-36$ & 8 & 2.8 & 1.9 & 0.3 \\
\hline SCS 90-36 & 9 & 2.9 & 17.9 & 44.4 & SCS $90-36$ & 12 & 3.4 & 2.5 & 0.4 \\
\hline SCS $90-36$ & 12 & 3.5 & 20.8 & 58.4 & SCS $90-36$ & 14 & 4.1 & 3.3 & 0.4 \\
\hline SCS 90-36 & 15 & 4.2 & 22.5 & 67.3 & SCS $90-36$ & 18 & 4.8 & 3.3 & 0.4 \\
\hline SCS 90-36 & 18 & 4.9 & 16.6 & 84.5 & SCS $90-36$ & 20 & 5.4 & 3.4 & 0.5 \\
\hline SCS 90-36 & 21 & 5.5 & 25.9 & 58.3 & SCS 90-36 & 24 & 6.1 & 1.8 & 0.3 \\
\hline SCS $90-36$ & 24 & 6.2 & 27.1 & 59.6 & SCS 90-36 & 26 & 6.8 & 1.7 & 0.3 \\
\hline SCS $90-36$ & 27 & 6.9 & 29.1 & 65.6 & SCS 90-36 & 30 & 7.4 & 1.2 & 0.3 \\
\hline SCS $90-36$ & 30 & 7.4 & 24.5 & 71.3 & SCS $90-36$ & 32 & 7.7 & 1.2 & 0.4 \\
\hline SCS 90-36 & 33 & 7.8 & 31.9 & 55.2 & SCS 90-36 & 36 & 8.2 & 1.3 & 0.3 \\
\hline SCS 90-36 & 36 & 8.3 & 34.8 & 65.9 & SCS 90-36 & 38 & 8.7 & 1.8 & 0.5 \\
\hline SCS $90-36$ & 39 & 8.8 & 27.3 & 78.6 & SCS 90-36 & 42 & 9.2 & 2.6 & 0.3 \\
\hline SCS 90-36 & 42 & 9.3 & 38.9 & 86.6 & SCS $90-36$ & 44 & 9.7 & 2.8 & 0.5 \\
\hline SCS $90-36$ & 45 & 9.8 & 32.5 & 85.6 & SCS $90-36$ & 48 & 10.2 & 2.8 & 0.5 \\
\hline SCS $90-36$ & 48 & 10.3 & 28.4 & 73.9 & SCS $90-36$ & 54 & 11.2 & 2.8 & 0.7 \\
\hline SCS $90-36$ & 51 & 10.8 & 41.9 & 92.3 & SCS $90-36$ & 56 & 11.7 & 2.3 & 0.7 \\
\hline SCS $90-36$ & 54 & 11.3 & 36.3 & 56.2 & SCS $90-36$ & 60 & 12.2 & 3.8 & 0.8 \\
\hline SCS $90-36$ & 57 & 11.8 & 36.0 & 88.8 & SCS 90-36 & 62 & 12.8 & 5.8 & 0.6 \\
\hline SCS $90-36$ & 60 & 12.3 & 41.8 & 75.2 & SCS $90-36$ & 66 & 13.0 & 2.6 & 0.5 \\
\hline SCS $90-36$ & 63 & 12.9 & 48.4 & 66.8 & SCS 90-36 & 68 & 13.2 & 3.7 & 0.6 \\
\hline SCS 90-36 & 66 & 13.0 & 46.6 & 72.5 & SCS 90-36 & 72 & 13.4 & 2.3 & 0.5 \\
\hline SCS $90-36$ & 69 & 13.2 & 42.2 & 78.4 & SCS $90-36$ & 74 & 13.6 & 3.9 & 0.7 \\
\hline SCS $90-36$ & 72 & 13.4 & 47.8 & 37.4 & SCS $90-36$ & 78 & 13.6 & 1.9 & 0.4 \\
\hline SCS 90-36 & 75 & 13.6 & 55.3 & 76.3 & $\operatorname{SCS} 90-36$ & 80 & 13.9 & 3.1 & 0.5 \\
\hline SCS $90-36$ & 78 & 13.7 & 55.2 & 66.2 & SCS $90-36$ & 84 & 14.1 & 3.0 & 0.5 \\
\hline $\operatorname{SCS} 90-36$ & 81 & 13.9 & 59.4 & 77.9 & SCS $90-36$ & 86 & 14.3 & 3.0 & 0.5 \\
\hline SCS $90-36$ & 87 & 14.3 & 51.9 & 72.0 & SCS 90-36 & 90 & 15.0 & 1.4 & 0.4 \\
\hline SCS $90-36$ & 90 & 15.1 & 41.1 & 78.9 & SCS 90-36 & 92 & 17.6 & 3.1 & 0.7 \\
\hline SCS 90-36 & 93 & 18.8 & 42.1 & 65.5 & SCS 90-36 & 96 & 21.3 & 2.0 & 0.6 \\
\hline SCS $90-36$ & 99 & 24.2 & 36.5 & 62.9 & SCS 90-36 & 98 & 23.9 & 2.7 & 0.6 \\
\hline SCS $90-36$ & 102 & 26.3 & 32.2 & 75.7 & SCS $90-36$ & 102 & 26.0 & 2.0 & 0.5 \\
\hline
\end{tabular}

${ }^{1} \mathrm{RSP}=$ Number of dissolution-resistant planktonic foraminifers (defined based on Cullen and Prell, 1984).

${ }^{2} \mathrm{WPF}=$ Number of whole planktonic foraminifers.

${ }^{3} \mathrm{FG}=$ Number of planktonic foraminifer fragments.

${ }^{4} \mathrm{~S}=$ Number of dissolution-susceptible nannofossil species.

${ }^{5} \mathrm{R}=$ Number of dissolution-resistant nannofossil species.

coming from nearby continental margins. Close examination indicates that the changes in carbonate contents as well as in carbonate accumulation rates (not shown) bear no obvious relationship to variations in the other preservation indices. Thus the index of carbonate content was excluded in our further computation of a composite preservation index.

\subsection{Composite Preservation Index (CPI)}

Most of the indices discussed above are also influenced by environmental variables other than carbonate preservation. For example, the number of fragments may be diminished by winnowing processes that result in sediment transfer to smaller size fractions. Ecological conditions may also cause 


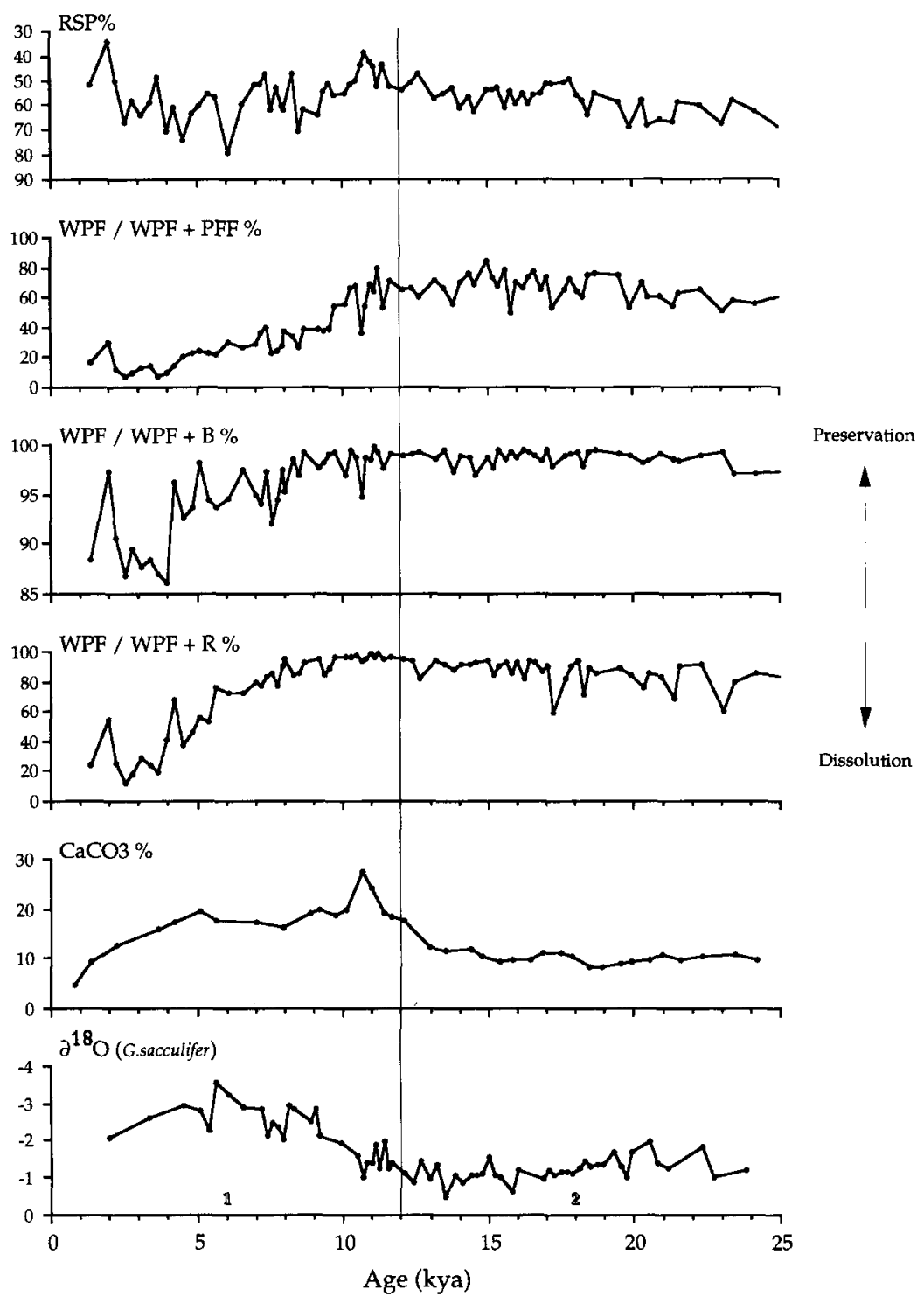

Fig. 3. Variations in carbonate preservation indices for core $31-\mathrm{KL}$, compared to downcore AMS ${ }^{14} \mathrm{C}$ dating and $\partial^{18} \mathrm{O}$ stratigraphy (G. sacculifer) and plotted against age. A line shows the boundary between $\partial^{18} \mathrm{O}$ stage 1 and stage 2 . Abbreviations for the preservation indices are explained in Table 3.

changes in the percentages of benthonic foraminifers and radiolarians. To extract the variance that is common among these preservation indices, we have used R-mode Principal Component Analyses (PCA) (Thunell, 1976; Peterson and Prell, 1985a,b) on the SCS 90-36 and 31-KL downcore preservation index data (Tables 3 and 4). These downcore data were interpolated by even time intervals $(\Delta t=0.75 \mathrm{k} . \mathrm{y}$. for SCS $90-36$ and $\Delta t=$ $0.30 \mathrm{k} . \mathrm{y}$. for $31-\mathrm{KL}$ ) before running the PCA. The width of these time intervals was chosen to be equivalent to the average temporal sampling of the two cores. The Composite Preservation Index (CPI) was then adopted as the first principal 
Table 3

Preservation indices of downcore samples from core $31-\mathrm{KL}$

\begin{tabular}{|c|c|c|c|c|c|c|}
\hline $\begin{array}{l}\text { Core } \\
\text { ID }\end{array}$ & $\begin{array}{l}\text { Depth } \\
(\mathrm{cm})\end{array}$ & $\begin{array}{l}\text { Age } \\
\text { (k.y.) }\end{array}$ & $\begin{array}{l}\text { RSP } \\
(\%)\end{array}$ & $\begin{array}{l}\mathrm{WPF} /(\mathrm{WPF}+\mathrm{FG}) \\
(\%)\end{array}$ & $\begin{array}{l}\mathrm{WPF} /\left(\mathrm{WPF}+\mathrm{BF}^{1}\right) \\
(\%)\end{array}$ & $\begin{array}{l}\mathrm{WPF} /\left(\mathrm{WPF}+\mathrm{R}^{2}\right) \\
(\%)\end{array}$ \\
\hline $31-K L$ & 5 & 1.4 & 51.8 & 17.1 & 88.4 & 24.3 \\
\hline $31-K L$ & 9 & 2.0 & 34.5 & 30.4 & 97.2 & 54.0 \\
\hline 31-KL & 11 & 2.2 & 50.6 & 11.8 & 90.6 & 25.1 \\
\hline $31-\mathrm{KL}$ & 13 & 2.5 & 66.7 & 7.4 & 86.8 & 12.1 \\
\hline $31-\mathrm{KL}$ & 15 & 2.8 & 58.3 & 9.3 & 89.6 & 17.7 \\
\hline $31-\mathrm{KL}$ & 17 & 3.1 & 64.0 & 12.8 & 87.7 & 29.4 \\
\hline 31-KL & 19 & 3.4 & 59.2 & 14.9 & 88.4 & 23.8 \\
\hline 31-KL & 21 & 3.7 & 48.9 & 7.8 & 87.0 & 19.8 \\
\hline 31-KL & 23 & 4.0 & 70.3 & 9.2 & 86.0 & 41.1 \\
\hline $31-\mathrm{KL}$ & 25 & 4.2 & 61.0 & 15.0 & 96.2 & 67.6 \\
\hline 31-KL & 27 & 4.5 & 73.9 & 20.2 & 92.6 & 37.1 \\
\hline $31-\mathrm{KL}$ & 29 & 4.8 & 63.5 & 22.3 & 93.7 & 45.8 \\
\hline $31-\mathrm{KL}$ & 31 & 5.1 & 60.6 & 24.6 & 98.1 & 55.3 \\
\hline $31-\mathrm{KL}$ & 33 & 5.4 & 55.4 & 22.8 & 94.4 & 53.2 \\
\hline $31-\mathrm{KL}$ & 35 & 5.7 & 56.4 & 21.3 & 93.6 & 75.5 \\
\hline 31-KL & 37 & 6.1 & 78.8 & 30.6 & 94.5 & 72.2 \\
\hline $31-\mathrm{KL}$ & 39 & 6.6 & 60.0 & 27.1 & 97.5 & 72.3 \\
\hline $31-\mathrm{KL}$ & 41 & 7.0 & 51.7 & 29.2 & 95.0 & 79.5 \\
\hline $31-\mathrm{KL}$ & 43 & 7.2 & 51.8 & 36.4 & 94.0 & 77.5 \\
\hline $31-\mathrm{KL}$ & 45 & 7.4 & 47.6 & 39.2 & 97.3 & 83.1 \\
\hline $31-\mathrm{KL}$ & 47 & 7.6 & 62.1 & 23.3 & 92.0 & 85.1 \\
\hline $31-\mathrm{KL}$ & 49 & 7.7 & 52.9 & 23.6 & 94.4 & 77.3 \\
\hline $31-\mathrm{KL}$ & 51 & 7.9 & 60.5 & 27.8 & 97.5 & 90.8 \\
\hline $31-\mathrm{KL}$ & 53 & 8.0 & 61.7 & 37.3 & 95.4 & 94.6 \\
\hline $31-K L$ & 55 & 8.3 & 47.7 & 33.5 & 98.6 & 84.3 \\
\hline $31-\mathrm{KL}$ & 57 & 8.5 & 70.6 & 27.1 & 96.9 & 85.7 \\
\hline $31-\mathrm{KL}$ & 59 & 8.7 & 61.8 & 38.7 & 99.4 & 92.9 \\
\hline $31-\mathrm{KL}$ & 65 & 9.2 & 63.7 & 38.6 & 97.6 & 95.4 \\
\hline $31-\mathrm{KL}$ & 67 & 9.4 & 54.9 & 37.6 & 98.2 & 84.7 \\
\hline 31-KL & 69 & 9.6 & 51.9 & 38.8 & 99.2 & 88.9 \\
\hline 31-KL & 71 & 9.8 & 55.8 & 53.9 & 99.2 & 96.5 \\
\hline $31-\mathrm{KL}$ & 75 & 10.1 & 55.0 & 55.6 & 97.0 & 96.3 \\
\hline $31-K L$ & 77 & 10.3 & 51.7 & 66.7 & 99.4 & 96.5 \\
\hline $31-\mathrm{KL}$ & 79 & 10.5 & 50.6 & 67.5 & 98.8 & 97.4 \\
\hline $31-\mathrm{KL}$ & 81 & 10.7 & 43.4 & 36.4 & 94.7 & 94.3 \\
\hline $31-\mathrm{KL}$ & 83 & 10.8 & 38.7 & 54.8 & 98.7 & 94.8 \\
\hline $31-\mathrm{KL}$ & 85 & 11.0 & 42.2 & 69.2 & 98.6 & 98.2 \\
\hline 31-KL & 87 & 11.1 & 44.3 & 63.3 & 99.7 & 96.8 \\
\hline 31-KL & 89 & 11.3 & 52.1 & 79.0 & 99.3 & 98.2 \\
\hline $31-K \mathbf{L}$ & 91 & 11.4 & 43.7 & 52.5 & 97.6 & 95.2 \\
\hline 31-KL & 96 & 11.7 & 52.5 & 70.7 & 99.0 & 97.0 \\
\hline $31-K L$ & 101 & 12.1 & 53.6 & 65.2 & 98.9 & 95.5 \\
\hline $31-\mathrm{KL}$ & 105 & 12.4 & 51.2 & 66.3 & 99.0 & 94.5 \\
\hline 31-KL & 109 & 12.7 & 47.3 & 60.0 & 99.2 & 82.2 \\
\hline $31-\mathrm{KL}$ & 117 & 13.2 & 57.6 & 70.8 & 98.5 & 94.1 \\
\hline $31-\mathrm{KL}$ & 121 & 13.5 & 55.1 & 65.7 & 99.4 & 91.3 \\
\hline $31-\mathrm{KL}$ & 125 & 13.8 & 52.8 & 55.5 & 97.3 & 88.2 \\
\hline 31-KL & 129 & 14.1 & 60.8 & 70.1 & 99.0 & 91.6 \\
\hline $31-\mathrm{KL}$ & 133 & 14.4 & 56.5 & 75.5 & 98.8 & 92.1 \\
\hline $31-\mathrm{KL}$ & 137 & 14.6 & 62.8 & 69.0 & 96.9 & 93.2 \\
\hline 31-KL & 145 & 15.0 & 53.6 & 84.7 & 98.7 & 93.5 \\
\hline $31-\mathrm{KL}$ & 149 & 15.2 & 54.0 & 73.7 & 97.6 & 84.7 \\
\hline
\end{tabular}


Table 3 (continued)

\begin{tabular}{|c|c|c|c|c|c|c|}
\hline $\begin{array}{l}\text { Core } \\
\text { ID }\end{array}$ & $\begin{array}{l}\text { Depth } \\
(\mathrm{cm})\end{array}$ & $\begin{array}{l}\text { Age } \\
\text { (k.y.) }\end{array}$ & $\begin{array}{l}\text { RSP } \\
(\%)\end{array}$ & $\begin{array}{l}\mathrm{WPF} /(\mathrm{WPF}+\mathrm{FG}) \\
(\%)\end{array}$ & $\begin{array}{l}\mathrm{WPF} /\left(\mathrm{WPF}+\mathrm{BF}^{1}\right) \\
(\%)\end{array}$ & $\begin{array}{l}\mathrm{WPF} /\left(\mathrm{WPF}+\mathrm{R}^{2}\right) \\
(\%)\end{array}$ \\
\hline 31-KL & 153 & 15.4 & 52.9 & 67.0 & 99.5 & 90.8 \\
\hline 31-KL & 157 & 15.6 & 61.1 & 77.9 & 98.6 & 92.8 \\
\hline $31-K L$ & 161 & 15.8 & 54.4 & 49.2 & 99.2 & 85.6 \\
\hline 31-KL & 165 & 16.0 & 59.4 & 70.2 & 98.8 & 92.2 \\
\hline $31-\mathrm{KL}$ & 169 & 16.2 & 55.1 & 66.0 & 99.4 & 81.6 \\
\hline $31-K L$ & 173 & 16.4 & 59.9 & 73.7 & 99.4 & 93.8 \\
\hline $31-K L$ & 177 & 16.6 & 56.3 & 77.6 & 98.9 & 92.6 \\
\hline $31-\mathrm{KL}$ & 181 & 16.9 & 55.2 & 65.4 & 98.4 & 86.5 \\
\hline $31-\mathrm{KL}$ & 185 & 17.1 & 51.7 & 73.1 & 99.5 & 90.0 \\
\hline $31-\mathrm{KL}$ & 189 & 17.3 & 51.4 & 52.9 & 97.8 & 59.2 \\
\hline $31-K L$ & 197 & 17.7 & 51.1 & 64.9 & 99.0 & 82.3 \\
\hline $31-\mathrm{KL}$ & 201 & 17.9 & 49.3 & 71.7 & 99.1 & 89.9 \\
\hline $31-\mathrm{KL}$ & 205 & 18.1 & 55.8 & 64.2 & 99.3 & 94.5 \\
\hline $31-K L$ & 209 & 18.3 & 58.3 & 60.5 & 97.8 & 71.4 \\
\hline $31-K L$ & 213 & 18.5 & 64.0 & 74.4 & 99.2 & 88.8 \\
\hline $31-\mathrm{KL}$ & 217 & 18.7 & 55.5 & 75.4 & 99.4 & 85.6 \\
\hline $31-\mathrm{KL}$ & 233 & 19.5 & 58.7 & 74.2 & 99.0 & 88.9 \\
\hline $31-\mathrm{KL}$ & 241 & 19.9 & 69.4 & 53.0 & 99.0 & 84.1 \\
\hline $31-K L$ & 249 & 20.4 & 58.4 & 69.7 & 98.1 & 76.4 \\
\hline $31-\mathrm{KL}$ & 253 & 20.6 & 68.0 & 60.1 & 98.3 & 85.3 \\
\hline $31-\mathrm{KL}$ & 261 & 21.0 & 66.3 & 59.9 & 99.0 & 82.7 \\
\hline $31-\mathrm{KL}$ & 269 & 21.4 & 67.0 & 54.0 & 98.5 & 68.1 \\
\hline $31-\mathrm{KL}$ & 273 & 21.6 & 58.6 & 63.0 & 98.3 & 90.6 \\
\hline $31-\mathrm{KL}$ & 281 & 22.3 & 60.7 & 64.8 & 98.9 & 92.1 \\
\hline $31-\mathrm{KL}$ & 289 & 23.1 & 67.7 & 50.2 & 99.4 & 60.8 \\
\hline $31-\mathrm{KL}$ & 293 & 23.5 & 57.8 & 57.6 & 97.1 & 79.1 \\
\hline $31-K L$ & 301 & 24.2 & 62.7 & 55.1 & 97.0 & 85.7 \\
\hline $31-K L$ & 313 & 25.3 & 71.9 & 62.7 & 97.5 & 81.7 \\
\hline
\end{tabular}

${ }^{1} \mathrm{BF}=$ Number of benthonic foraminifers.

${ }^{2} \mathrm{R}=$ Number of radiolarians.

Table 4

SCS 90-36: Factor scores for the Composite Preservation Index (CPI) and the average percentage of variance for each downcore preservation index explained by the CPI

\begin{tabular}{lll}
\hline $\begin{array}{l}\text { Preservation } \\
\text { indices }\end{array}$ & $\begin{array}{l}\text { Factor scores } \\
\text { for CPI }\end{array}$ & $\begin{array}{l}\text { Variance explained } \\
(\%)\end{array}$ \\
\hline -RSP (\%) & -0.54 & 29.2 \\
WPF/(WPF + FG) (\%) & 0.63 & 39.7 \\
Nanno-S (\%) & 0.80 & 64.0 \\
Nanno-S/(S+R) (\%) & 0.88 & 77.5 \\
\hline
\end{tabular}

Total variance explained $=52.6 \%$.

component, which accounts for about $52 \%$ and $76 \%$ of the variance in the SCS $90-36$ and $31-\mathrm{KL}$ data, respectively (Tables 4 and 5). Well preserved sediments are indicated by more positive CPI
Table 5

31-KL: Factor scores for the Composite Preservation Index (CPI) and the average percentage of variance for each downcore preservation index explained by the CPI

\begin{tabular}{lll}
\hline $\begin{array}{l}\text { Preservation } \\
\text { indices }\end{array}$ & $\begin{array}{l}\text { Factor scores } \\
\text { for CPI }\end{array}$ & $\begin{array}{l}\text { Variance explained } \\
(\%)\end{array}$ \\
\hline- RSP (\%) & 0.64 & 41.0 \\
WPF/(WPF + FG) (\%) & 0.89 & 79.2 \\
WPF/(WPF + BF) (\%) & 0.96 & 92.2 \\
WPF/(WPF + R) (\%) & 0.96 & 92.2 \\
\hline
\end{tabular}

Total variance explained $=76.2 \%$.

values, whereas poorly preserved sediments are indicated by more negative values (Fig. 4).

Examination of the factor scores reveal different degrees of correlation between the preservation 


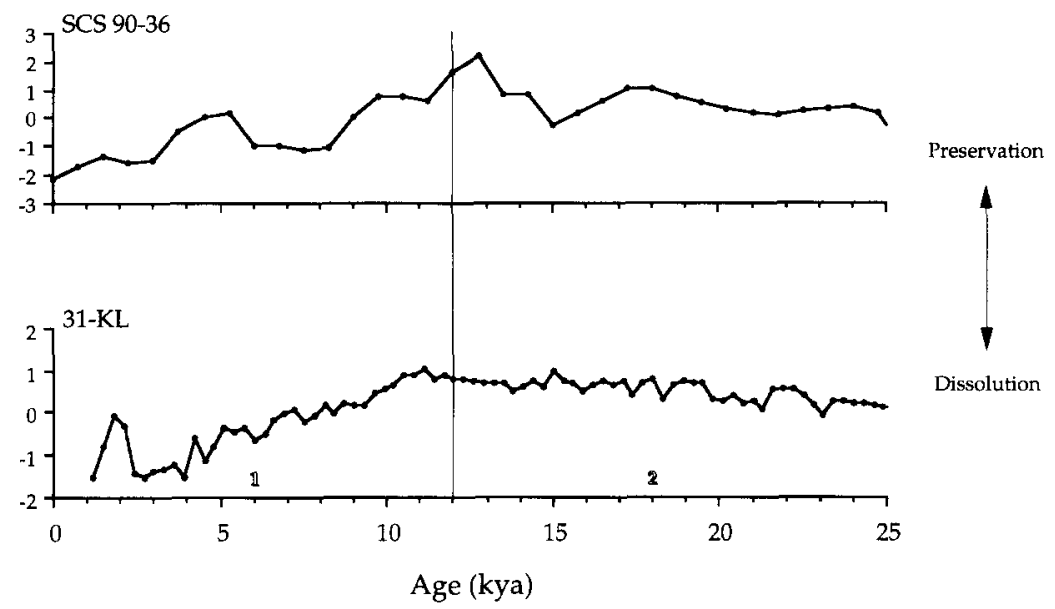

Fig. 4. Composite preservation index (CPI) for cores SCS 90-36 and 31-KL. Positive values indicate enhanced preservation and negative values indicate greater dissolution. A line shows the boundary between stage 1 and stage 2 of the $\partial^{18} \mathrm{O}$ stratigraphy.

indices and the CPI (Tables 4 and 5). Squaring the value of each factor score gives the average percentage of variance for each index explained by the CPI. The variance unaccounted for by the CPI indicates that other processes, such as local ecology, sediment transport, and/or winnowing, may affect the carbonate preservation index. In both cores, all indices except for RSP\% indicate high values of the factor loadings. In fact, core SCS 90-36 revealed a negative correlation of RSP\% with CPI. This relationship indicates that the processes other than preservation/dissolution may affect the variations of $\mathrm{RSP} \%$. A recent analysis (Chen, 1994) using Pacific coretop planktonic foraminifer data has already shown a dominant ecological control of thermocline depth which influences the abundance changes of these dissolution-resistant species.

\section{Results}

Over the past $25 \mathrm{k} . \mathrm{y}$., the CPI curves for the two deep sea cores are quite similar. Both cores show preservation levels that are relatively higher before Termination I (from 25 k.y. through 12 k.y.) compared to those after Termination I. In addition, we also observe a trend in which the degree of preservation increases steadily from 25 k.y. up to $12 \mathrm{k} . \mathrm{y}$. Carbonate preservation reached maximal levels around Termination $\mathrm{I}$, and then began its steady decline to the present level (Fig. 4). This change in carbonate preservation was also observed in the western equatorial Pacific between 12 and 13 k.y. and has been considered an excellent stratigraphic marker (Berger, 1977; Berger and Killingley, 1977). Close examination indicates that the CPI record from core $31-\mathrm{KL}$ show not only glacial-to-interglacial fluctuations ( $1 / f$ on the order of $10^{4} \mathrm{yr}$ ) but also high frequency oscillations ( $1 / f$ on the order of $\leq 10^{3} \mathrm{yr}$ ) (Fig. 4), which suggests there may be multiple sources producing this variability. The presence of these high frequency oscillations is certainly due to the higher sedimentation rates in this core. However, at this stage, we do not rule out the possibility that these oscillations are only random noise signals.

Because several preservation indices were used to extract the CPI, the preservation states of these two cores can not be directly compared. The shallower core SCS 90-36 $(2050 \mathrm{~m})$ was drilled well above the modern lysocline $(3000 \mathrm{~m})$ so this core is assumed to have better preservation than 
31-KL, which was taken from within or below the lysocline $(3360 \mathrm{~m})$. When compared by a common index generated for both cores (WPF\%= $(\mathrm{WPF} /(\mathrm{WPF}+\mathrm{PFF}) \times 100))$, we found that prior to Termination I, there was no noticeable preservation difference between these two cores. After Termination I, however, sediments from core 31-KL appear to have experienced stronger dissolution conditions than core SCS 90-36. At this time, the values of WPF\% of core $31-\mathrm{KL}$ sediments decreased from a maximum of $60 \%$ to values falling near $20 \%$ (Fig. 3 ). In contrast, the index of core SCS 90-36 sediments exhibited much higher WPF\% values with a maximum value of $90 \%$ falling to a minimum of $40 \%$, indicating better preservation (Fig. 2).

The above observation demonstrates a glacial/interglacial preservation fluctuation occurring in SCS sediments. The data indicate that preservation fluctuations in SCS deep sea cores exhibit a Pacific-type pattern with good preservation during glacial periods and poor preservation during interglacial periods. These records show that the preservation fluctuations are not synchronous with the glacial/interglacial change, but appear to be somewhat offset. The period of maximum preservation occurred during the Termination I, a period of rapid deglaciation, rather than during the latter glacial period. Our high resolution records also show that, as indicated by AMS ${ }^{14} \mathrm{C}$ dating and oxygen isotope stratigraphy, this maximum preservation event occurred between 13 and $11 \mathrm{kya}$. Similar observations of a preservation spike occurring during deglaciation stages have been reported elsewhere, primarily in the tropical Indian and Pacific Oceans (Berger, 1977; Berger and Killingley, 1977; Peterson and Prell, 1985b; Farrell and Prell, 1989, 1991).

\section{Discussion}

Our results show that over the past 25,000 yr, changes in the level of carbonate preservation occurred in SCS deep sea sediments from about 2000 to $3000 \mathrm{~m}$ water depths. These carbonate preservation changes took place during the last glacial-to-interglacial transition period and follow a similar temporal pattern as other preservation records from the tropical Indian and Pacific Oceans. This indicates that the SCS pattern reflects a regional carbonate response that is probably driven by global changes in deep water circulation, variations in surface water productivity, or a combination of both factors.

The deep water in the SCS is well ventilated through exchange with the western tropical Pacific. The sill that separates the SCS from the western tropical Pacific is estimated to lie at $2500-2600 \mathrm{~m}$, which allows Pacific intermediate and deep waters to enter the SCS (Thunell et al., 1992). A hydrographic study (Gong et al., 1992) of the SCS west of the Luzon Strait also reported similarities of deep water properties between the SCS and western Philippine Sea (WPS), suggesting the presence of inflow through the Luzon Strait from the WPS to the SCS. In this light, the deep sea preservation records from the SCS may also provide a good opportunity to examine variations in Pacific deep water ventilation and chemistry, though the preservation signals in SCS records can be more complicated due to the marginal sea effects of local productivity or organic matter remineralization in the water column.

Deep waters in the Pacific Ocean originate mostly from a mixture of both North Atlantic and Antarctic waters. Though a potential regional source of glacial Pacific deep waters is still under investigation, existing evidence of such a local deep water source is inconclusive (Corliss et al., 1986; Keigwin, 1987; Curry et al., 1988). The processes that control deep water formation in the North Atlantic are very sensitive to climatic changes. In the present-day ocean, NADW forms and accumulates $\mathrm{CO}_{2}$ oxidized from organic matter descending from surface waters. Through a large-scale transportation system driven by thermohaline circulation (Broecker and Denton, 1989), NADW is transported to the deep basins of the Pacific, and as a consequence the Pacific deep waters are more corrosive so that levels of carbonate preservation are low. During the last glacial stage, however, the production of NADW was diminished relative to that of Antarctic Bottom Water and a general slowing of deep and bottom water circulation occurred. Thus, less $\mathrm{CO}_{2}$ was transported into deep Pacific waters so that the level of carbonate preservation increased in the glacial deep Pacific. 
Our records from the SCS clearly show a Pacifictype of preservation pattern, with good preservation from 25 k.y. through Termination I, and low preservation from the end of Termination I to the present. This would suggest that the SCS preservation pattern is primarily controlled by processes of basin-to-basin fractionation of deep waters as suggested by Berger and Winterer (1974).

Geochemical models (Broecker and Peng, 1987; Boyle, 1988) designed for explaining the glacialto-interglacial variation of atmospheric $p \mathrm{CO}_{2}$ have successfully predicted the carbonate preservation spike observed across Termination I in the present SCS study. In the Broecker and Peng (1987) model, the preservation spike in the deep ocean at the time of deglaciation resulted from an adjustment of the ocean carbonate system to nutrient changes. In this model, the rise of atmospheric $p \mathrm{CO}_{2}$ at the time of the last deglaciation was caused by less efficient surface water productivity and upwelling, which in turn decreased the content of $\mathrm{CO}_{2}$ and increased the carbonate ion concentration $\left(\mathrm{CO}_{3}^{2-}\right)$ in deep waters. The preservation spike recorded in deep sea sediments basically reflects the sudden increase of $\mathrm{CO}_{3}^{2-}$ in deep waters. In response to the sudden increase of $\mathrm{CO}_{3}^{2-}$, the rate of carbonate removal of the ocean is increased through more rapid burial of carbonate sediments on the sea floor. Restoring the ocean carbonate system to its initial state by this manner took several thousand years (Broecker and Peng, 1987). In the Boyle (1988) model, a mechanism of vertical nutrient transfer was proposed to explain the preservation spike. During the last deglaciation period when the global thermohaline circulation pattern was reorganized, changes in intermediate and deep water production rates caused nutrient and $\mathrm{CO}_{2}$ to transfer from deep to intermediate waters. This resulted in $\mathrm{CO}_{3}^{2-}$ concentrations in deep waters to increase abruptly, producing a preservation spike in deep sea sediments. As in the model proposed by Broecker and Peng (1987), the carbonate system took several thousand years to restore to its initial state, leading to a gradual increase in atmospheric $p \mathrm{CO}_{2}$.

These models suggest that carbonate preservation of SCS deep sea sediments is primarily controlled by mechanisms dependent on global ocean processes. The consistency between the temporal pattern of SCS preservation during the last $25,000 \mathrm{yr}$ and that predicted by global geochemical models (Broecker and Peng, 1987; Boyle, 1988) strongly suggests that the SCS deep waters are well ventilated by inflows from western Pacific deep waters, which is consistent with the observation of regional hydrography.

In addition to the influence of changes in deep water circulation, local productivity variations may also play a significant role in shaping preservation patterns. On examining differences in the preservation levels from cores SCS 90-36 (above modern lysocline) and 31-KL (below modern lysocline), we found that the gradient of dissolution increases after 25 k.y., with the record from core $31-\mathrm{KL}$ exhibiting stronger dissolution than SCS 90-36 after Termination I. The temporal change of preservational gradients within this part of SCS waters (2050-3360 m) may indicate a gradual shoaling of the regional lysocline after $25 \mathrm{k} . \mathrm{y}$. The lysocline shoaling in the SCS may either reflect a decrease in the state of $\mathrm{CO}_{3}^{2-}$ saturation of Pacific deep waters or less deep water exchange between the WPS and SCS. It could also be caused by a decrease of $\mathrm{CaCO}_{3}$ productivity and/or an increase of organic (siliceous) productivity in SCS surface waters. If productivity changes are indeed one of the important controls in carbonate preservation in the SCS, strong precession-related cycles (23 k.y.) should be found in our records. Recent studies (Huang et al., in press) indicate that the variation of surface ocean productivity in the SCS is closely associated with the intensity of the Asian winter monsoon systems, which are largely regulated by precession cycles as well-documented by many other studies (Prell, 1984a,b; Clemens et al., 1991). However, the present records from cores SCS $90-36$ and $31-\mathrm{KL}$ are not long enough to permit spectral identification of precession cycles. Longer records containing more precession cycles and analysis of proxy indices for productivity changes from the sedimentary records will help verify this prediction.

\section{Conclusions}

A study of variations in carbonate preservation indices over the past $25 \mathrm{k} . \mathrm{y}$. in two SCS cores, 
SCS $90-36$ and $31-\mathrm{KL}$, reveal a clear change in carbonate preservation between the last glacial and interglacial periods. A preservation spike that peaked during Termination I, the last deglaciation period $(\sim 12,000 \mathrm{k} . \mathrm{y}$.$) , is also clearly preserved in$ these records. This overall pattern is similar to that reported in the western Pacific and suggests that similarities in deep water circulation prevailed during the late Quaternary in the SCS and the western Pacific. These data confirm the observation that preservation maxima tend to occur during the latter part of glacial stages, as shown previously in many Indian and Pacific deep sea core studies.

\section{Acknowledgements}

This research was supported by the National Science Council (NSC84-2611-M-019-013) and the National Taiwan Ocean University, Republic of China.

\section{References}

Archer, D.E., 1991. Equatorial pacific calcite preservation cycles: production or dissolution? Paleoceanography, 6: $561-571$.

Arrhenius, G., 1952. Sediment cores from the east Pacific. In: H. Petterson (Editor), Rep. Swed. Deep-Sea Exped. 1947-1948, 5: 1-228.

Arrhenius, G., 1988. Rate of production, dissolution, and accumulation of biogenic solids in the ocean. Palaeogeogr. Palaeoclimatol, Palaeoecol., 67: 119-146.

Barnola, J.M., Raynaud, D., Korotkevich, Y.S. and Lorius, C., 1987. Vostok ice core provides 160,000 -year record of atmospheric $\mathrm{CO}_{2}$. Nature, 329: 408-414.

Bassinot, F.C., Beaufort, L., Vincent, E., Labeyrie, L.D., Rostek, F., Müller, P.J., Quidelleur, X. and Lancelot, Y., 1994. Coarse fraction fluctuations in pelagic carbonate sediments from the tropical Indian Ocean: a 1500-kyr record of carbonate dissolution. Paleoceanography, 9: 579-600.

Berger, W.H., 1967. Foraminiferal ooze: solution at depth. Science, 156: 383-385.

Berger, W.H., 1968. Planktonic foraminifera: selective solution and paleoclimatic interpretation. Deep Sea Res., 15: 31-43.

Berger, W.H., 1977. Deep-sea carbonate and the deglaciation preservation spike in pteropods and foraminifera. Nature, 269: 301-304.

Berger, W.H. and Winterer, E.L., 1974. Plate stratigraphy and the fluctuating carbonate line. In: K.J. Hsü and H.C. Jenkyns
(Editors), Pelagic Sediments on Land and Under the Sea. IAS Spec. Publ., 1: 11-48.

Berger, W.H. and Killingley, J.S., 1977. Glacial-Holocene transition in deep-sea carbonates: selective dissolution and the stable isotope signal. Science, 197: 563-566.

Berger, W.H., Bonneau, M.-C. and Parker, F.L., 1982. Foraminifera on the deep-sea floor: lysocline and dissolution rate. Oceanol. Acta, 5: 249-258.

Bian, Y., Wang, P. and Zheng, L., 1992. Deep-water dissolution cycles of late Quaternary planktonic foraminifera in the South China Sea (in Chinese). In: Z. Ye and P. Wang (Editors), Contributions to Late Quaternary Paleoceanography of the South China Sea. Qingdao Ocean Univ. Press, pp. $261-273$.

Biekart, J.W., 1989. The distribution of calcareous nannoplankton in late Quaternary sediments collected by the Snellius II Expedition in some southeast Indonesian basins. Proc. $\mathrm{K}$. Ned. Akad. Wet. Ser. B., 92: 77-141.

Boyle, E.A., 1988. The role of vertical chemical fractionation in controlling late Quaternary atmospheric carbon dioxide. J. Geophys. Res., 93: 701-714.

Broecker, W.S., 1982a. Glacial to interglacial changes in ocean chemistry. Progr. Oceanogr., 11: 151-197.

Broecker, W.S., 1982b. Ocean chemistry during glacial time. Geochim. Cosmochim. Acta, 46: 1689-1705.

Broecker, W.S. and Peng, T.-H., 1987. The role of $\mathrm{CaCO}_{3}$ compensation in the glacial to interglacial atmospheric $\mathrm{CO}_{2}$ change. Global Biogeochem. Cycles, 1: 15-29.

Broecker, W.S. and Denton, G.H., 1989. The role of ocean-atmosphere reorganizations in glacial cycles. Geochim. Cosmochim. Acta, 53: 2465-2501.

Chen, M.-T., 1994. Estimating thermocline from planktonic foraminifer faunal data: the development of paleoecological transfer functions for reconstructing low-latitude Pacific upper-layer conditions. J. Geol. Soc. China (Taipei), 37: 443-474.

Cheng, X., 1992. Distribution of calcareous nannofossil abundance in late Quaternary sediments from central and northern parts of South China Sea: a preliminary study (in Chinese). In: Z. Ye and P. Wang (Editors), Contributions to Late Quaternary Paleoceanography of the South China Sea. Qingdao Ocean Univ. Press, pp. 274-282.

Chuey, J.M., Rea, D.K. and Pisias, N.G., 1987. Late Pleistocene paleoclimatology of the central equatorial Pacific: a quantitative record of eolian and carbonate deposition. Quat. Res., 28: 323-339.

Clemens, S.C., Prell, W.L., Murray, D., Shimmield, G. and Weedon, G., 1991. Forcing mechanisms of the Indian Ocean monsoon. Nature, 353: 720-725.

Corliss, B.H., Martinson, D.G. and Keefer, T., 1986. Late Quaternary deep-ocean circulation. Geol. Soc. Am. Bull., 97 : 1106-1121.

Cullen, J.L. and Prell, W.L., 1984. Planktonic foraminifera of the northern Indian Ocean: distribution and preservation in surface sediments. Mar. Micropaleontol., 9: 1-52.

Curry, W.B. and Lohmann, G.P., 1986. Late Quaternary car- 
bonate sedimentation at the Sierra Leone Rise (eastern equatorial Atlantic). Mar. Geol., 70: 223-250.

Curry, W.B., Duplessy, J.-C., Labeyrie, L.D. and Shackleton, N.J., 1988. Changes in the distribution of $\partial^{13} \mathrm{C}$ of deep water $\sum \mathrm{CO}_{2}$ between the last glaciation and the Holocene. Paleoceanography, 3: 317-341.

Damuth, J.E., 1975. Quaternary climatic change as related by calcium carbonate fluctuations in western equatorial Atlantic sediments. Deep-Sea Res., 22: 725-743.

Farrell, J.W. and Prell, W.L., 1989. Climatic change and $\mathrm{CaCO}_{3}$ preservation: an 800,000 year bathymetric reconstruction from the central equatorial Pacific Ocean. Paleoceanography, 4: 447--466.

Farrell, J.W. and Prell, W.L., 1991. Pacific $\mathrm{CaCO}_{3}$ preservation and $\partial^{18} \mathrm{O}$ since $4 \mathrm{Ma}$ : paleoceanic and paleoclimatic implications. Paleoceanography, 6: 485-498.

Gardner, J.V., 1975. Late Pleistocene carbonate dissolution cycles in the eastern equatorial Atlantic. In: W.L. Sliter et al. (Editors), Dissolution of Deep-Sea Carbonates. Cushman Found. Foraminif. Res. Spec. Publ., 13: 129-141.

Gong, G.-C., Liu, K.K., Liu, C.-T. and Pai, S.-C., 1992. The chemical hydrography of the South China Sea west of Luzon and a comparison with the west Philippine Sea. TAO, 3: $587-602$.

Howard, W.R. and Prell, W.L., 1994. Late Quaternary $\mathrm{CaCO}_{3}$ production and preservation in the Southern Ocean: implications for oceanic and atmospheric carbon cycling. Paleoceanography, 9: 453-482.

Huang, C.-Y., Wu, S.-F., Zhao, M., Chen, M.-T., Wang, C.-H., Tu, X. and Yuan, P.B., in press. Surface ocean and monsoon climate variability in the south China Sea since last glaciation. Mar. Micropaleontol.

Imbrie, J., Hay, J.D., Martinson, D.G., McIntyre, A., Mix, A.C., Morley, J.J., Pisias, N.G., Prell, W.L. and Shackleton, N.J., 1984. The orbital theory of Pleistocene climate: support from a revised chronology of the marine ${ }^{18} \mathrm{O}$ record. In: A.L. Berger et al. (Editors), Milankovitch and Climate, Part I. Reidel, Dordrecht, pp. 269-305.

Keigwin, L.D., 1987. North Pacific deep water formation during the latest glaciation. Nature, 330: 362-364.

Kudrass, H.R., Jin, X.L., Bieerstorf, H. and Cepek, P., 1992. Erosion and sedimentation in the Xisha Trough at the continental margin of Southern China. In: J. Xianglong et al. (Editors), Marine Geology and Geophysics of the South China Sea. China Ocean Press, Hangzhou, pp. 137-147,

Le, J. and Shackleton, N.J., 1992. Carbonate dissolution fluctuations in the western equatorial Pacific during the late Quaternary. Paleoceanography, 7: 21-42.

Matsuoka, H. and Okada, H., 1989. Quantitative analysis of Quaternary nannoplankton in the subtropical northwestern Pacific Ocean. Mar. Micropaleontol., 14: 97-118.

Naidu, P.D., Malmgren, B.A. and Bornmalm, L., 1993. Quaternary history of calcium carbonate fluctuations in the western equatorial Indian Ocean (Somali Basin). Palaeogeogr. Palaeoclimatol. Palaeoecol., 103: 21-30.

Parker, F.L. and Berger, W.H., 1971. Faunal and solution pat- terns of planktonic foraminifera in surface sediments of the South Pacific. Deep Sea Res., 18: 73-107.

Peterson, L.C. and Prell, W.L., 1985a. Carbonate dissolution in recent sediments of the eastern equatorial Indian Ocean: preservation patterns and carbonate loss above the lysocline. Mar. Geol., 64: 259-290.

Peterson, L.C. and Prell, W.L., 1985b. Carbonate preservation and the rates of climatic change: an $800 \mathrm{kyr}$ record from the Indian Ocean. In: E.T. Sundquist and W.S. Broecker (Editors), The Carbon Cycle and Atmospheric $\mathrm{CO}_{2}$ : Natural Variations Archean to Present (Geophys. Monogr., 32). AGU, Washington, DC, pp. 251-269.

Prell, W.L. 1984a. Variation of monsoon upwelling: a response to changing solar radiation. In: J.E. Hansen and T. Takahashi (Editors), Climate Processes and Climate Sensitivity (Geophys. Monogr., 29). AGU, Washington, DC, pp. 48-57.

Prell, W.L., 1984b. Monsoonal climate of the Arabian Sea during the late Quaternary: a response to changing solar radiation. In: A.L. Berger (Editor), Milankovitch and Climate. Reidel, Dordrecht, 1, pp. 349-366.

Prell, W.L., Imbrie, J., Martinson, D.G., Morley, J.J., Pisias, N.G., Shackleton, N.J. and Streeter, H.F., 1986. Graphic correlation of oxygen isotope stratigraphy: application to the late Quaternary. Paleoceanography, 1: 137-162.

Rahman, A. and Roth, P.H., 1989. Late Neogene calcareous nannofossil biostratigraphy of the Gulf of Aden Region. Mar. Micropaleontol., 15: 1-27.

Rottman, M.L., 1979. Dissolution of planktonic foraminifera and pteropods in South China Sea sediments. J. Foraminif. Res., 9: 41-49.

Ruddiman, W.F., 1971. Pleistocene sedimentation in the equatorial Atlantic: stratigraphy and faunal paleoclimatology. Geol. Soc. Am. Bull., 82: 283-302.

Shackleton, N.J., 1977. Carbon-13 in Uvigerina: tropical rainforest history and the equatorial Pacific carbonate dissolution cycles. In: N.R. Andersen and A. Malahoff (Editors), The Fate of Fossil Fuel $\mathrm{CO}_{2}$ in the Oceans. Plenum Press, New York, pp. 401-427.

Thompson, P.R., 1976. Planktonic foraminiferal dissolution and the progress towards a Pleistocene equatorial Pacific transfer function. J. Foraminif. Res., 6: 208-227.

Thunell, R.C., 1976. Optimum indices of calcium carbonate dissolution in deep-sea sediments. Geology, 4: 525-528.

Thunell, R.C., 1982. Carbonate dissolution and abyssal hydrography in the Atlantic Ocean. Mar. Geol., 47: 165-180.

Thunell, R.C. and Honjo, S., 1981. Calcite dissolution and the modification of planktonic foraminiferal assemblages. Mar. Micropaleontol., 6: 169-182.

Thunell, R.C., Keir, R. and Honjo, S., 1981. Calcite dissolution: an in situ study in the Panama Basin. Science, 212: 659-661.

Thunell, R.C., Miao, Q., Calvert, S.E. and Pedersen, T.F., 1992. Glacial-Holocene biogenic sedimentation patterns in the South China Sea: productivity variations and surface water $p \mathrm{CO}_{2}$. Paleoceanography, 7: 143-162.

Valencia, M.J., 1977. Pleistocene stratigraphy of the western equatorial Pacific. Geol. Soc. Am. Bull., 88: 143-150. 
Wang, H. and Jian, Z., 1992. Carbonate dilution cycles in the late Quaternary South China Sea. In: Z. Ye and P. Wang (Editors), Contributions to Late Quaternary Paleoceanography of the South China Sea. Qingdao Ocean Univ. Press, pp. 283-294 (in Chinese).

Wang, L., 1992. Late Quaternary pteropods and aragonite compensation depth in the northern South China Sea. In: Z. Ye and P. Wang (Editors), Contributions to Late Quaternary Paleoceanography of the South China Sea. Qingdao Ocean Univ. Press, pp. 249-260 (in Chinese).

Wei, K.-Y., Yang, T.-N. and Huang, C.-Y., in press. Glacial-Holocene calcareous nannofossils and paleoceanography in the northern South China Sea. Mar. Micropaleontol. 